\author{
Radosław KRZEMIŃSKI ${ }^{1}$ \\ Wojciech TERLIKOWSKI ${ }^{2}$
}

\title{
KASZYCE DREWNIANE - HISTORYCZNYM ELEMENTEM REWITALIZACJI ZABYTKÓW
}

\begin{abstract}
Kaszyce jako masywne mury oporowe stosowane są od ok. VIII wieku do umacniania skarp i zboczy, brzegów rzek, potoków i osuwisk, zapewniając stateczność stromym brzegom oraz chroniąc ich podstawę przed rozmyciem. Przestrzenna struktura konstrukcji wypełniona materiałem przepuszczalnym znakomicie wpisuje się w wymagania stawiane konstrukcji gdzie problemem staje się parcie hydrostatyczne, osiadanie a także hałas i estetyka. Konstrukcja kaszyc posiada dużą odkształcalność i wpływa to znacząco na odporność na nierównomierne osiadanie. Nawet kilkudziesięciocentymetrowe różnice osiadań nie powodują uszkodzeń konstrukcji oporowej. Zaletą takiej cechy jest możliwość posadawiania kaszyc w strefie przemarzania gruntów. Dodatkowo istnieje możliwość obsadzenia takiej konstrukcji oporowej roślinnością pnącą potęguje pozytywny efekt estetyczny oraz podkreśla walory historyczne kompleksu zabytkowego. Wytyczne konserwatorskie stawiają za jeden z głównych celi wpisywanie się konstrukcji wzmacniającej w historyczny wygląd otoczenia zabytku a przede wszystkim nie pogarszał jego walorów estetycznych. Przykładem takiego obiektu budowlanego są ruiny zamku na wzgórzu zamkowym w Sochaczewie. W roku 2013 wykonano wzmocnienie wzgórza zamkowego poprzez wykorzystanie gwoździ gruntowych, masywnej ściany oporowej w konstrukcji kaszycowej oraz nasypów zbrojonych geosyntetykami. Efektem końcowym zabezpieczenia wzgórza zamkowego konstrukcją kaszycy jest powstanie drewnianej skrzynia wypełnionej kruszywem mineralnym. Geometria masywnej konstrukcji oporowej to kaszyca o długość 79,8 m i szerokości $1,65 \mathrm{~m}$ zaś nachylenie ściany oporowej to przepisowe 4:1. Kaszycę posadowiono na żelbetowym fundamencie bezpośrednim. W artykule przedstawiono zabezpieczenie nasypu budowlanego przy wykorzystaniu drewnianej konstrukcji kaszyc jako masywnej ściany oporowej.
\end{abstract}

Słowa kluczowe: masywny mur oporowy, ściana oporowa, kaszyca, konstrukcja kaszycowa, zabytek, wzmocnienie skarp, wzmocnienie osuwisk

\footnotetext{
${ }^{1}$ Autor do korespondencji: Radosław Krzemiński; Politechnika Warszawska Wydział Inżynierii Lądowej, Ove Arup \& Partners Int. Ltd Sp. z o.o.; Al.Armii Ludowej 16, 00-637 Warszawa; telefon: 607-780-316; email: radek.krzem@interia.pl.

2 Wojciech Terlikowski; Politechnika Warszawska Wydział Inżynierii Lądowej, Al.Armii Ludowej 16, 00-637 Warszawa; telefon: 602-630-513; email: w.terlikowski@il.pw.edu.pl.
} 


\section{Wstęp}

\subsection{Mury oporowe}

Norma PN-83/B-03010 [1] definiuje ściany oporowe jako budowle, które utrzymują $\mathrm{w}$ stanie statycznym uskok naziomu gruntów rodzimych oraz gruntów nasypowych, a także innych materiałów rozdrobnionych, sypkich takich jak: kruszywo, węgiel, żużel itp. Generalnie mury oporowe wymiennie nazywane ścianami oporowymi utrzymują w stanie statycznej równowagi uskoki naziomów materiałów, które charakteryzują się parametrami geotechnicznymi takimi jak: gęstość $\gamma\left[\mathrm{kN} / \mathrm{m}^{3}\right]$, kąt tarcia wewnętrznego $\Phi\left[{ }^{0}\right]$, spójność $c[\mathrm{kPa}]$, moduł odkształcenia pierwotnego $E_{0}[M P a]$ czy współczynnik odkształcenia bocznego (współczynnik Poissona) $v$.

Mury oporowe stosuje się do budowy: przyczółków kolejowych i mostowych, nabrzeży zbiorników wodnych i składów materiałów sypkich, ścian śluz, oraz do zabezpieczenia stateczności skarp i stoków.

Ściany oporowe ze względu na ich konstrukcję można podzielić na masywne (ciężkie) i lekkie (kątowe).

Ze względu zaś na materiał użyty do wykonania konstrukcji ścian oporowych dzielimy je na ściany: żelbetowe (prefabrykowane i wylewane na mokro na budowie), kamienne, murowane, stalowe, drewniane i syntetyczne (geosyntetyki użyte do budowy zabezpieczenia skarpy).

Podział ścian oporowych ze względu na rodzaj pracy konstrukcji [3] rozróżnić można następujące typy:

a) ściany masywne,

b) ściany masywne ze wspornikowymi płytami odciążającymi,

c) ściany płytowo-kątowe,

d) ściany płytowo-żebrowe,

e) ściany specjalne, np. palisadowe (wspornikowe).

Masywne mury oporowe są to ściany o dużej szerokości przekroju poprzecznego, przeciwstawiające się parciu gruntu czy innego materiału swoim ciężarem i tarciem podstawy o podłoże. Stateczność masywnych ścian oporowych zapewnia ich ciężar własny

Masywne mury oporowe wykonuje się z kamienia, pustaków betonowych i cegły oraz wylewane $\mathrm{z}$ betonu. Czasami, gdy jest wysoka ściana muru silnie obciążona parciem gruntu, konieczne jest zastosowanie wspornika lub jednej, a nawet więcej płyt odciążających. W ten sposób zmniejsza się niezbędny ciężar ściany oporowej. Płyta wspornika, obciążona gruntem wywołuje dodatkową siłę skupioną i odwrotnie skierowany moment zginający w ścianie, powiększając naprężenia ściskające na krawędzi od strony gruntu. Płyta odciążająca zwiększa jednocześnie stateczność muru. 
Obliczanie statyczno-wytrzymałościowe masywnych ścian oporowych nie jest skomplikowane, albowiem schematy obliczeniowe są proste zaś wzory obliczeniowe parć materiału gruntowego na ścianę, są powszechnie znane.

Celem samym w sobie w czasie fazy projektowania, kiedy wymagane jest znacznie zaangażowania projektanta, jest prawidłowe i odpowiednie ukształtowanie geometrii ściany oraz jej posadowienia tj. fundamentu. Szczególną uwagę należy zwrócić na dobór pochylenia ściany a zwłaszcza jej powierzchni podstawy. Przyczynia się to znaczącego zredukowania składowej stycznej do wypadkowej podstawy obliczeniowych obciążeń w poziomie posadowienia. Pozwala to na spełnienie warunku stanu granicznego na przesuw oraz na wypieranie gruntu spod podstawy fundamentu ściany oporowej. Pochylenie konstrukcji ściany oporowej zwłaszcza jej tylnej ściany (tj. tej łączącej się z gruntem), zmniejszając tym samym parcie gruntu oszczędza zużycie materiału na poziomie około $25 \%$. Jednak nie można przesadzić, gdyż zbyt duże pochylenie masywnej ściany oporowej, doprowadzić może do utraty stateczności konstrukcji ściany przed zasypaniem jej gruntem. Konieczne jest wówczas prowadzenie równoczesnych prac wznoszących ścianę oraz jej zasypywanie.

\section{Kaszyce}

\subsection{Historia kaszyc}

Kaszyce są masywnymi murami oporowymi o przestrzennej strukturze konstrukcji. Rozpoczęto ich używanie od ok. VIII wieku do zabezpieczania brzegów rzek, potoków i osuwisk, a także skarp oraz zboczy. Zapewniano tym samym stateczność stromym brzegom i chroniono ich podstawy przed rozmyciem. Szczególnie kaszycowe konstrukcje wykorzystywano zwłaszcza na tych odcinkach cieków, gdzie brzeg był niestateczny z uwagi na jego pionowość. Kaszycowe ściany oporowe były zwłaszcza rekomendowane na tych odcinkach cieków wodnych, gdzie na brzegach narażonych na podcinanie posadowione były obiekty budowlane oraz nasadzenia drzew. Stwarzało to wysokie ryzyko utraty stateczności konstrukcji budowli. Obecnie również jest to jeden z powodów, gdzie spotyka się takie właśnie wykorzystanie kaszyc. Kaszyce stosowane są również, jako podpory mostów. Często stopnie wodne (zwane progami lub stopniami kaszycowymi) przy melioracji i retencjonowaniu cieków wodnych lub rzek wykonywane są w technologii kaszycowej. Badania archeologiczne pokazują, że od momentu pojawienia się w inżynierii rozwiązań kaszycowych były to konstrukcje drewniano-kamienne. Na początku używano bali drewnianych lub kłód zaś współcześnie konstrukcje kaszyc wykonywane są z żelbetowych elementów prętowych zaś rzadziej z drewnianych czy też stalowych.

Konstrukcje masywnych murów oporowych, jako kaszyc używano bardzo często jeszcze w XX w, zaś obecnie niestety zmalało zainteresowanie taką kon- 
strukcją mimo jej wielu zalet o czy w dalszej części niniejszego dokumentu autorzy będą przekonywać. W minionym wieku bardzo często stosowano kaszyce do konstruowania podpór mostów drewnianych [10]. Szczególnie znajdowały zastosowanie $\mathrm{w}$ warunkach, w których nie można było wbić pali w dno rzeki. Biorąc równocześnie pod uwagę dużą głębokość wody oraz rozmycie dna bardzo dobrym rozwiązaniem były filary kaszycowe. Kształt takiej konstrukcji był skrzynią prostopadłościenną (lub w rzucie wieloboczną), wykonaną z drewna, a wnętrze jej wypełniane było kamieniami.

Przestrzenna struktura konstrukcji kaszyc wypełniana była i jest obecnie najczęściej materiałem kamiennym, kruszywem lub gruzem (współcześnie z rozbiórek konstrukcji żelbetowych, jako materiał ekonomicznie uzasadniony do użycia) a pierwotnie gruntem i kamieniami.

\subsection{Konstrukcja kaszyc}

Historycznie rozpoczęto wykonywanie kaszyc z elementów drewnianych bali jak wspomniano powyżej. Do wykonania przestrzennej drewnianej konstrukcji kaszyc konieczne jest stosowanie drewno odpornego na butwienie. Stąd rekomendowane jest wykorzystanie pni gatunków twardych drzew. Średnica Typową średnicą drewnianych bali jest wielkość ok. $15 \mathrm{~cm}$, a dla wysokich konstrukcji kaszycowych średnica oczywiście jest nieco większa. Natomiast współczesne realizacje pokazują wykonywanie konstrukcji kaszyc z różnych materiałów takich jak przedstawiono na zdjęciach poniżej.

Jednym z pierwszych zastosowań w kraju kaszyc żelbetowych było wykonanie z nich tymczasowej grodzy dla potrzeb budowy zapory w Solinie [5].

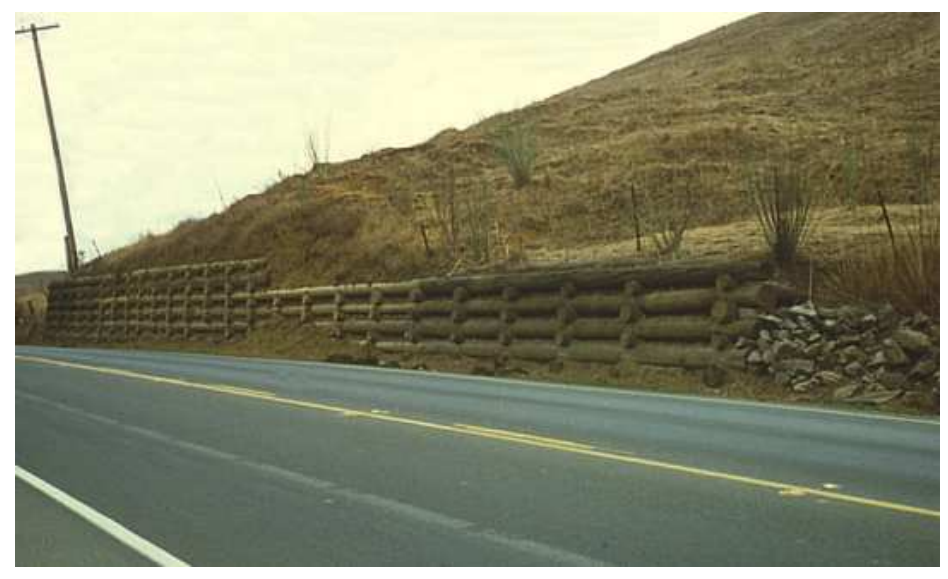

Rys. 1. Przykład ściany kaszycowej z bali drewnianych

Fig. 1. Example of crib retaining wall with wooden logs 


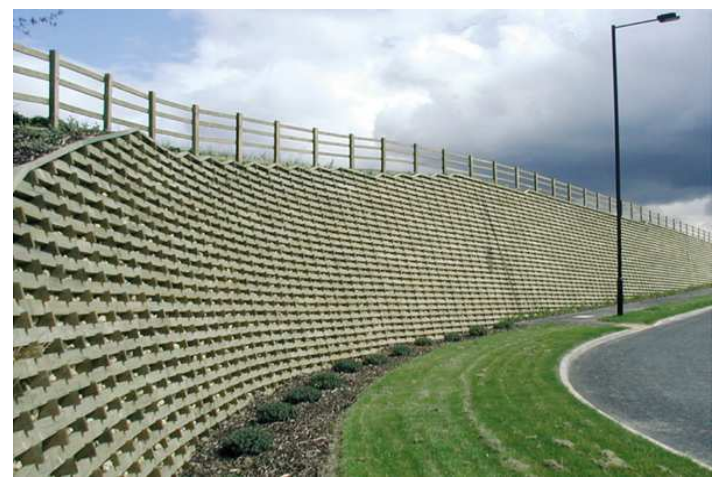

Rys. 2. Przykład kaszycy z drewnianych elementów

Fig. 2. Example of timber crib retaining wall

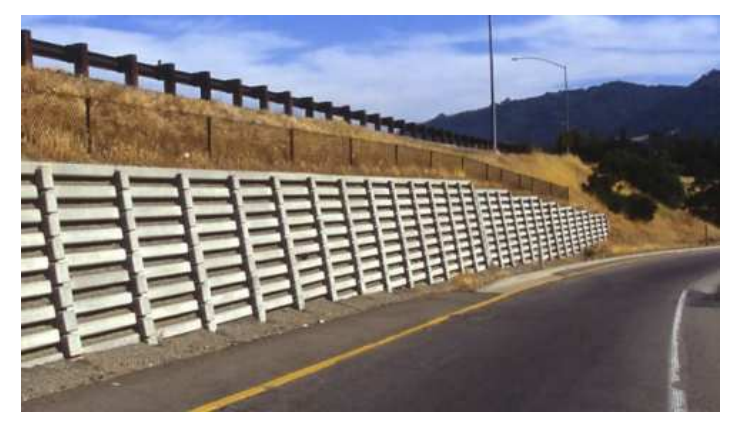

Rys. 3. Przykład kaszycy wykonanej z prefabrykatów

Fig. 3. Example of timber crib wall

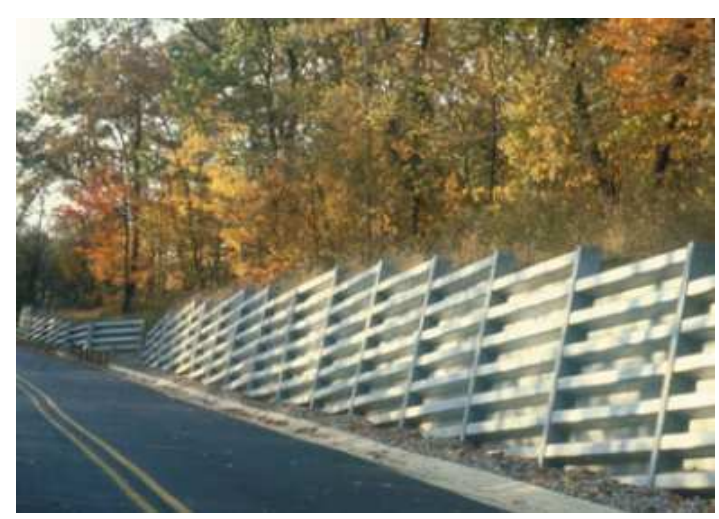

Rys. 4. Przykład ściany kaszycowej ze stalowych profili Fig. 4. Example of crib retaining wall with steel profiles 


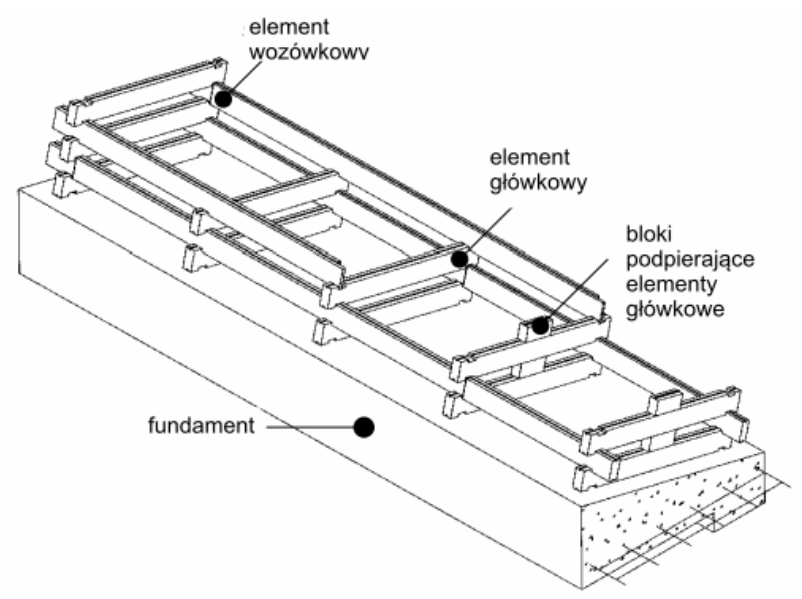

Rys. 5. Przykład ściany kaszycowej firmy Phi Group Ltd, na podstawie [6]

Fig. 5. Example of crib wall by Phi Group Ltd company, based on [6]

Przykładem współczesnej kaszycy drewnianej jest PERMACRIB z elementów dostarczanych przez brytyjską firmę Phi Group Ltd [6]. Przygotowane drewniane elementy kaszycy ciśnieniowo są nasycone ochronnym środkiem CCA, w celu całkowitego wypełnienia nim komórek drewna, aby zabezpieczyć go przed owadami i grzybami. Taka technologia przygotowania pozwala zapewnić przydatność użytkową kaszycy nawet ponad 125 lat. Firma Phi Group Ltd. udziela gwarancję na konstrukcję nawet na 60 lat.

Konstrukcja kaszyca wykonywana jest z prefabrykowanych elementów drewnianych: poprzecznych (elementy główkowe) i podłużnych (elementy wozówkowe). Przy końcach elementów poprzecznych (główki) znajdują się nacięcia o szerokości równej szerokości elementu podłużnego. Nacięcia te służą do wykonania połączeń ciesielskich elementów poprzecznych z podłużnymi. Wznoszenie ściany polega na naprzemiennym układaniu elementów poprzecznych i podłużnych wraz z sukcesywnym wypełnianiem kaszycy materiałem zasypowym. W efekcie powstaje drewniana skrzynia wypełniona kruszywem mineralnym.

Elementy wozówkowe mają kształt belek o przekrojach kwadratowych lub prostokątnych, elementy główkowe posiadają podobny kształt, jednakże na ich końcach uformowane są zaczepy, które przejmują siły rozpierające ścianę oporową. Szerokość elementów podłużnych przyjmuje się z warunku [5]:

$$
b A \geq 2 h B
$$

gdzie: $b A$ - szerokość prefabrykatu A,

$h B$ - wysokość przekroju prefabrykatu główkowego wyznaczająca światło pionowe między sąsiednimi prefabrykatami podłużnymi; zaleca się mniejszą niż $20 \mathrm{~cm}$. 
Zachowanie tego warunku pozwala na to, że wypełniający kaszycę suchy grunt nie wysypuje się przez otwory między prefabrykatami podłużnymi.

Wnętrze kaszycy jest wypełniane kamieniami, tłuczniem, pospółką lub innym gruntem przepuszczalnym. Materiał wypełniający powinien być dobrze zagęszczony. Dopiero potem zasypuje się konstrukcję oporową. Orientacyjnie przyjmuje się szerokość kaszycy na podstawie poniższego wzoru:

$$
b k=(0,4 h-1,0) h
$$

gdzie: $h$ - jest jej wysokością.

Stateczność kaszycy sprawdza się tak, jak oblicza się inne typy masywnych ścian oporowych. Średnią gęstość wypełnionej kaszycy można przyjmować na poziomie $1600 \mathrm{~kg} / \mathrm{m}^{3}$. W celu zwiększenia stateczności konstrukcji kaszycy realizowane jest jej pochylenie w stronę zasypu, najczęściej w zakresie do $5: 1$.

Konstrukcja kaszyc posiada dużą odkształcalność i wpływa to znacząco na odporność na nierównomierne osiadanie. Nawet kilkudziesięciocentymetrowe różnice osiadań nie powodują uszkodzeń konstrukcji oporowej. Zaletą takiej cechy jest możliwość posadawiania kaszyc w strefie przemarzania gruntów. Zaleca się jednak zagłębienie konstrukcji kaszycy w grunt do około $60 \mathrm{~cm}$. Należy pamiętać, aby w kaszycy i w jej sąsiedztwie nie tworzyły się zastoiska wody, które osłabiają materiał drewnianej kaszycy. Przeciwdziałaniem i ochroną jest wypełnienie materiałem o małej przepuszczalności wody (np. gliną) wnętrza kaszycy oraz otaczającego ją wykopu do poziomu terenu. W wypadku, gdy nośność gruntu nie pozwala na przeniesienie obciążenia konstrukcji oporowej bez znacznych osiadań, wówczas układa się na gruncie kilka elementów podłużnych kaszycy i na nich montuje kaszycę. W sytuacji, gdy zabieg ten nie jest wystarczający, konstrukcję kaszycy opiera się na płycie fundamentowej betonowej lub żelbetowej. Konieczność taka zachodzi w przypadku budowy wysokich konstrukcji oporowych. Należy jednak zaznaczyć, że w razie stosowania kaszyc, jako trwałych konstrukcji oporowych, jest wskazane oparcie ich na około 50-centymetrowej warstwie betonu lub gruntu stabilizowanego również, gdy mają nieznaczną wysokość. Warstwa taka pozwala wyrównać osiadania kaszyc.

Nośność kaszyc sprawdzana jest tak jak dla typowych masywnych murów oporowych oraz uwzględnia się dodatkowe charakterystyczne dla tego typu konstrukcji elementy. Stąd stany graniczne nośności konstrukcji kaszyc rozpatrywane powinny być dla przywołanych przypadków zniszczenia konstrukcji (Rys. 6). 

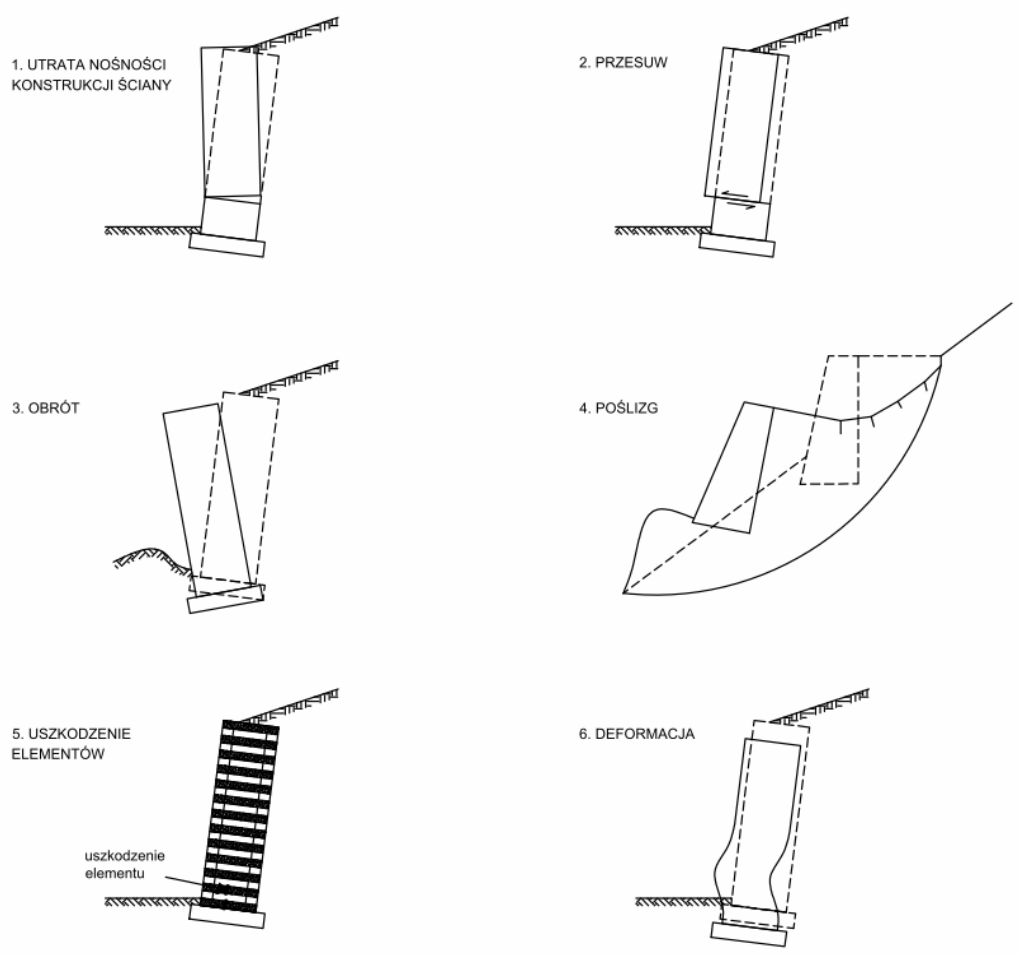

Rys. 6. Stany graniczne zniszczenia kaszycy na podstawie [4]

Fig. 6. Limit modes of crib retaining wall failure based on [4]

Zaletami konstrukcji kaszycowej są również następujące cechy:

a) prefabrykowanie elementów konstrukcji,

b) dobre odwodnienie zasypki - brak parcia hydrostatycznego,

c) zróżnicowana wysokość konstrukcji - łatwość montażu,

d) waga elementów; prostota montażu ( $3 \mathrm{~m}^{2} /$ osobogodz),

e) montaż nie wymaga wykwalifikowanej kadry robotniczej oraz specjalnego osprzętu i maszyn,

f) tłumienie hałasu,

g) walory estetyczne i proekologiczne - mogą być porośnięte pnączami lub kwiatami.

Jest znamienne, że w krajach zachodnich wśród argumentów uzasadniających użycie kaszyc wymienia się na pierwszym miejscu estetyczność tej odmiany konstrukcji oporowych. Taka opinia może wzbudzać zdziwienie, jednakże jest faktem częste stosowanie tam kaszyc przy autostradach i w miejscach eksponowanych widokowo. Porośnięte zielenią kaszyce harmonizują w sposób naturalny z otaczającym terenem, czego na ogół nie można powiedzieć np. o betonowych ścianach oporowych, które z czasem pokrywają się rysami skurczowymi i uszkodzeniami korozyjnymi oszpecającymi budowle. 


\subsection{Konstrukcja kaszyc a zabytki}

Konstrukcja kaszyc znakomicie nadaje się do zabezpieczania skarp, osuwisk, miejsc gdzie występują obiekty podlegające ochronie konserwatorskiej. Znakomicie współgrają nawet z zabytkami znajdującymi się w stanie „trwałej ruiny". Współpraca projektanta z konserwatorem zabytków jest nieodzowna i należy pamiętać, aby przed podjęciem działań konserwatorskich i budowlanych (w tym remontowych), konieczne była wykonana dokładna diagnostyka obiektu historycznego [7][8]. Przykładem zabytkowego obiektu budowlanego, przy którym zastosowano konstrukcję kaszyc są ruiny zamku w Sochaczewie. W zabezpieczeniu wzgórza zamkowego, na którym znajdował się zamek, wykorzystano drewniane kaszyce.

Historia wzgórza zamkowego w Sochaczewie [9] jest barwna, sięga początkiem XIII wieku, kiedy to książę Konrad I Mazowiecki wzniósł drewniano-ziemną warownię Piastów Mazowieckich. Zamek w ciągu swoich dziejów był rozbudowywany, burzony, odbudowywany fragmentarycznie, zaś w 1794 roku, podczas insurekcji kościuszkowskiej, został ostatecznie zniszczony. Od tego momentu pozostawał w ruinie i niszczał. Także wzgórze będące właściwie nasypem ziemnym podlegało wielokrotnym reprofilacjom i wzmocnieniom, wynikającym z jego niestateczności i degradacji. Główną czynnikami destrukcyjnymi dla wzgórza były oddziaływania klimatyczne i środowiskowe, a szczególnie opady deszczu, powodujące erozję powierzchniową i wgłębną. Dopiero w roku 2013 wykonano wzmocnienie wzgórza zamkowego poprzez wykorzystanie gwoździ gruntowych, ściany oporowej w konstrukcji kaszycowej oraz nasypów zbrojonych geosyntetykami.

Na podstawie badań geotechnicznych i archiwalnych badań archeologicznych ustalono, że wzgórze zamkowe zbudowane jest z nasypów piaszczystych (piaski i piaski pylaste) o różnej miąższości, od 1,6 do 7,5 m, zaś podłoże naturalne stanowią piaski gliniaste, gliny piaszczyste oraz lokalnie piaski pylaste.

Swobodne zwierciadło wody gruntowej zostało nawiercono na głębokości odpowiednio 1,5 m (skarpa północna), na głębokości 2,0 m p.p.t. (skarpa zachodnia) i u podstawy wzgórza, od strony północnej i zachodniej.

Nasypy na skarpie północnej, zachodniej oraz w południowo - wschodnim narożniku wzgórza zazbrojono geosyntetykami, jako zabezpieczenie przeciwerozyjne.

Na skarpie zachodniej dobudowano nasyp zbrojonego geosyntetykami na całej wysokości skarpy. Posadowienie nasypu zbrojonego wykonano na palach żelbetowych CFA, ze względu na występowanie gruntów słabych w podstawie skarpy.

W narożniku południowo-wschodnim, w celu zwiększenia odległości pomiędzy murami zamku a pierwotną skarpą wzgórza, zaprojektowano obudowanie narożnika nasypem z gruntu zbrojonego. Nasyp zbrojony wykonano zgodnie z projektem o nachyleniu 1:1,5 i wysokości $8,5 \mathrm{~m}$. 


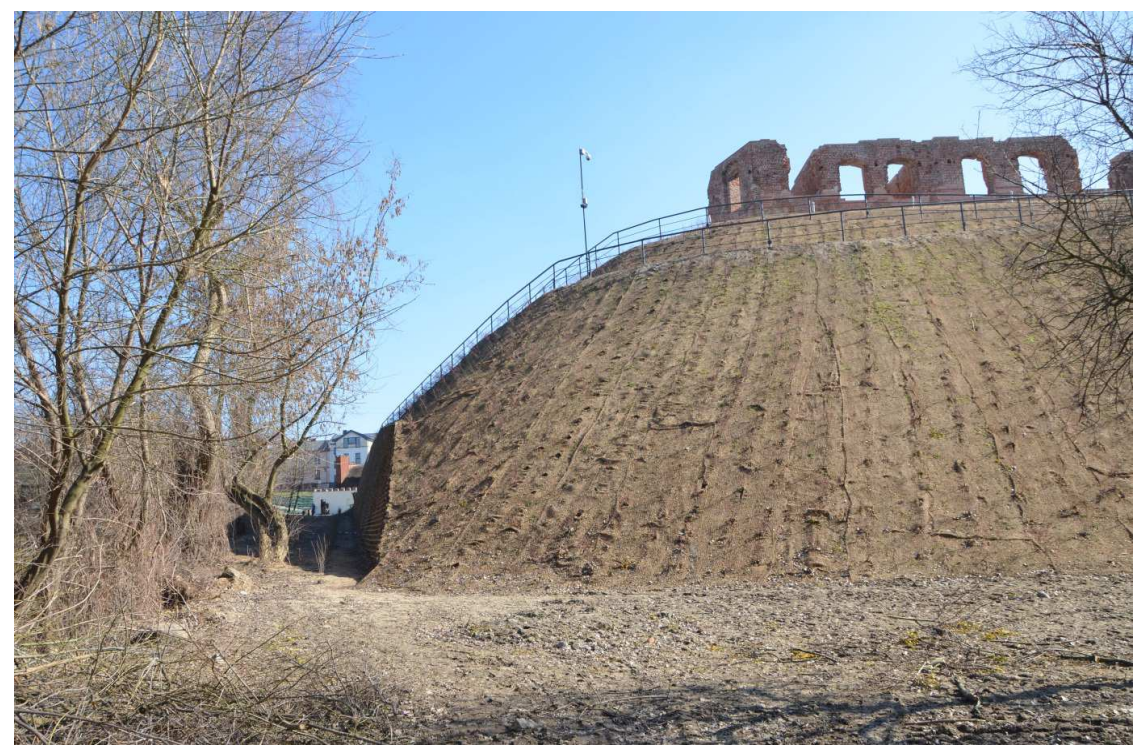

Rys. 7. Widok ściany oporowej kaszycowej i ruin zamku w Sochaczewie

Fig. 7. View of crib retaining wall and castle of ruins in Sochaczew

Ograniczenia przestrzenne po północnej stronie wzgórza (brak możliwości zajęcia sąsiednich działek oraz występowanie miejskiego kolektora kanalizacyjnego), u podstawy skarpy północnej wykonano ścianę kaszycową użycie, której uzgodnił projektant z konserwatorem zabytków. Ściana oporowa o zmiennej wysokości, utrzymując uskok naziomu od 0,8 do 7,0 m. Niestety ze względu na niedostateczną stateczność ogólną skarpy północnej, przed przystąpieniem do wznoszenia konstrukcji kaszycy wykonano wzmocnienie poprzez wykonanie gwoździ gruntowych. Zainstalowano gwoździe o nachyleniu $10^{\circ}$ do poziomu, w rozstawie $1,5 \mathrm{~m}$ w poziomie na $1,5 \mathrm{~m}$ w pionie. Gwoździ gruntowych tymczasowo wzmacniały skarpę przed wykonaniem ściany oporowej oraz dodatkowo docelowo kotwią kaszycę w gruncie rodzimym. Zabieg taki był możliwy po uprzednim wydłużeniu zainstalowanych w skarpie gwoździ i połączeniu ich z konstrukcją drewnianej kaszycy. Na powierzchni gwoździowanej istniejącej skarpy, pod głowicami gwoździ, ułożono płyty drogowe typu IOMB, w celu rozdystrybuowania naprężeń pochodzących z poszczególnych gwoździ na powierzchnię skarpy. Od korony ściany oporowej do rzędnej 90,5 m npm wykonano nasyp zbrojony geosyntetykami, w postaci geotkanin poliestrowych. Powyżej zbrojonego nasypu wykonano nasyp niezbrojony, o nachyleniu 1:2,5.

Ścianę kaszycową wznoszono z prefabrykowanych elementów drewnianych. Przy końcach elementów poprzecznych znajdują się nacięcia o szerokości równej szerokości elementu podłużnego. Nacięcia te służą do wykonania połączeń ciesielskich elementów poprzecznych z podłużnymi. Wznoszenie ściany 
polegało na naprzemiennym układaniu elementów poprzecznych i podłużnych wraz z sukcesywnym wypełnianiem kaszycy materiałem zasypowym, jak pokazano na zdjęciu poniżej (Rys 8).

Efekt końcowy to powstanie drewnianej skrzynia wypełnionej kruszywem mineralnym. Długość powstałej konstrukcji kaszycy wynosi 79,8 m przy szerokości 1,65 m zaś nachylenie ściany oporowej to przepisowe 4:1. Kaszycę posadowiono na żelbetowym fundamencie bezpośrednim. Za podstawą ściany ułożono rury drenarskiej w obsypce żwirowej, w osłonie z geowłókniny filtracyjnej. Dren ma za zadanie odprowadzać wodę gruntowej z zasypu niespoistego, znajdującego się w przestrzeni pomiędzy ścianą oporową a powierzchnią istniejącej skarpy. Powyżej masywnej ściany oporowej wykonano nasyp zbrojony o nachyleniu 1:1.

Stateczność kaszycy analizowano poprzez założenie zastępczej bryły gruntu spoistego, zakotwionego w masywie skarpy wzgórza, za pomocą przedłużonych gwoździ gruntowych. W przyjętym modelu obliczeniowym oporowa ściana kaszycowa stanowi, zatem jedynie oblicowanie dla skarpy, zbrojonej gwoździami gruntowymi. Stateczność konstrukcji kaszycy sprawdzono poprzez analizę

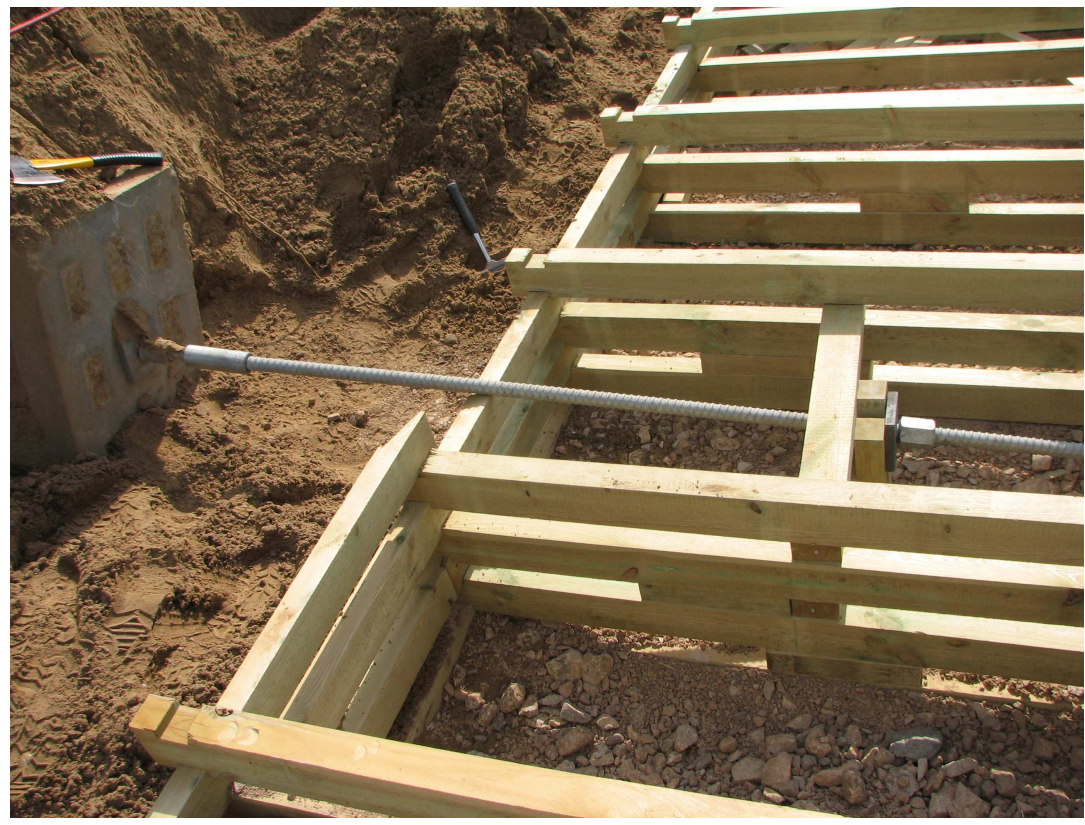

Rys. 8. Widok ściany oporowej kaszycowej, płyt oporowych IOMB, połączenia gwoździ gruntowych z konstrukcją kaszycy, oraz montażowe nacięcia w drewnianych elementach kaszycy oraz materiał zasypowy

Fig. 8. View of crib retaining wall, retaining plates IOMB, the connection of crib wall with extended soil nails, mounting notches in timber elements and the filling material 


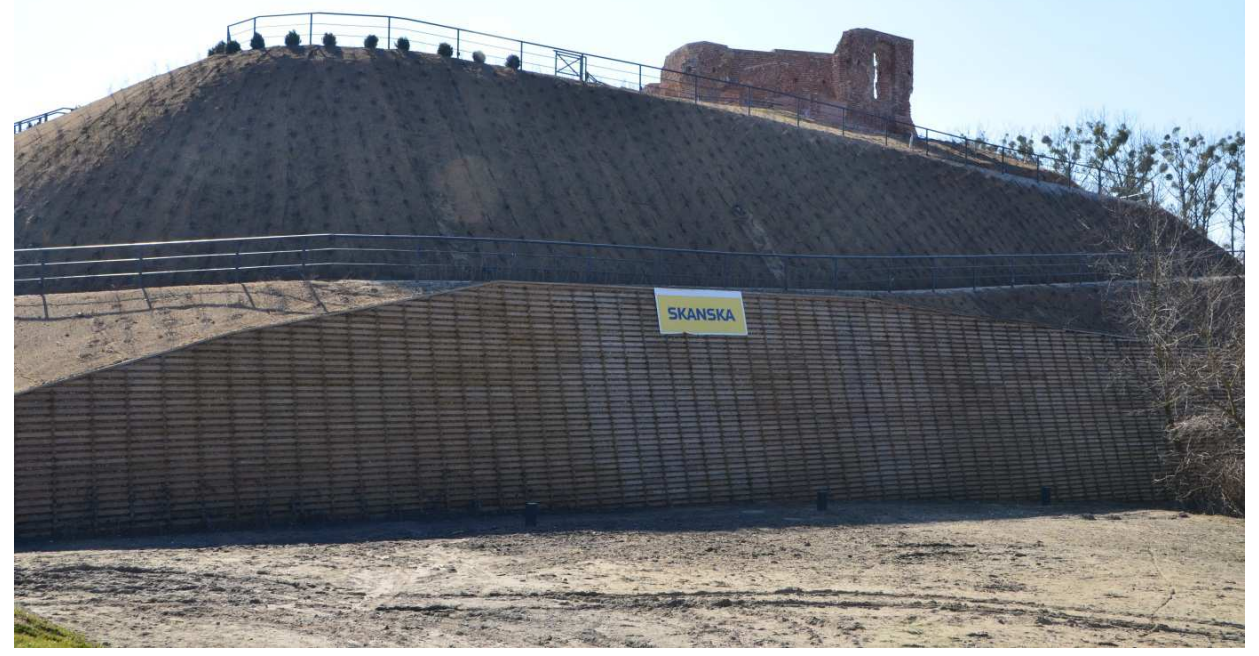

Rys. 9. Widok ściany oporowej kaszycowej i ruin zamku w Sochaczewie

Fig. 9. View of crib retaining wall and castle of ruins in Sochaczew

kołowych oraz łamanych powierzchni poślizgu. Do analizy przyjmowano zarówno wymuszone powierzchnie poślizgu w podstawie ściany oraz na połączeniu ze skarpą istniejącą, a także zoptymalizowane powierzchnie poślizgu, o najniższym możliwym współczynniku stateczności. Przeprowadzone obliczenia pokazały minimalny osiągnięty współczynniki stateczności o wartości F > 1,5. Stateczność ściany kaszycowej zapewniona jest dzięki ciężarowi ściany przeciwdziałającemu siłom wywracającym a przede wszystkim dzięki zakotwieniu ściany w masywie wzgórza za pomocą gwoździ gruntowych.

Kaszyce wypełniono kruszywem łamanym o odpowiednim uziarnieniu [9], zaś ścieralność kruszywa nie większą niż 50 oznaczono w bębnie Los Angeles [2]. Konstrukcję ściany oporowej wznoszono warstwami po trzy rzędy, przy założeniu, że jeden rząd tworzy komplet elementów podłużnych i poprzecznych. Po wzniesieniu trzech rzędów kaszycy, przestrzeń za konstrukcją ściany oporowej wypełniano gruntem zasypowym a następnie starannie zagęszczano do wymaganego wskaźnika zagęszczenia. Po wypełnieniu przestrzeni za ścianą, przystępowano do wypełnienia wnętrze kaszycy kruszywem i zagęszczono je. Ze wznoszeniem konstrukcji ściany oporowej układano równocześnie zbrojenie zasypu i łączono gwoździe gruntowe z kaszycą. 


\section{Podsumowanie}

Konstrukcja kaszyc jest znana i sprawdzona w wielu różnorodnych realizacjach. Konstrukcja kaszyc są stabilne i łatwe do wykonywania, znakomicie dostosowując się do nierównomierności terenu. Z ekonomicznego punktu widzenia, biorąc pod uwagę koszt materiału, niewykwalifikowanej robocizny oraz czas wznoszenia, konstrukcja kaszyc plasuje się wysoko, jako oszczędny mur oporowy. Kaszyce drewniane ze względu na dużą możliwość odkształcania, znakomicie zastępują betonowe umocnienia brzegów płynących cieków wodnych. Wielowiekową historię konstrukcji kaszyc znakomicie podkreśla atut kaszyc przy zabezpieczaniu osuwisk i wzgórz w bezpośrednim sąsiedztwie obiektów budowlanych będących zabytkami podlegających ochronie konserwatorskiej. Możliwość obsadzenia takiej konstrukcji oporowej roślinnością pnącą potęguje pozytywny efekt estetyczny oraz podkreśla walory historyczne kompleksu zabytkowego. Przykład wzmocnienia wzgórza zamkowego w Sochaczewie za pomocą kaszycy drewnianej w ocenie autorów bardzo dobrze komponują się z zabytkiem. Potwierdza to także pozytywna opinia konserwatora zabytków, gdyż wyeksponowany obiekt zabytkowy nie jest przytłoczony elementem konstrukcyjnym, który obecnie, mimo że, jest widoczny w pełni docelowo będzie ukryty za roślinnością go porastającą.

Projektując konstrukcje kaszyc należy jednak pamiętać o społecznym czynniku. Uzgadniać go należy każdorazowo z administratorami terenu, gdzie powstać ma taka właśnie masywna ściana oporowa. Forma konstrukcji kaszyc znajdujących się w miejscu publicznym, może być zachętą do niebezpiecznych praktyk takich jak wspinaczka, co w konsekwencji może być źródłem wypadków. Wymusza oczywiście takie niebezpieczeństwo prowadzenie stałego monitoringu (wideo) konstrukcji a także odpowiednie oznakowanie tablicami informacyjnymi oraz ostrzegającymi terenu wokół kaszycy.

\section{Literatura}

[1] PN-83/B-03010 Ściany oporowe. Obliczenia statyczne i projektowanie. Warszawa, Wydawnictwo Normalizacyjne „ALFA”, 1983 (z późniejszymi zmianami).

[2] PN-B-06714-42:1979P: Kruszywa mineralne. Badania. Oznaczanie ścieralności w bębnie Los Angeles.

[3] Cios I., Garwacka-Piórkowska S.: Projektowanie fundamentów, Warszawa, Oficyna wydawnicza Politechniki Warszawskiej, 2003.

[4] Design Manual for Roads and Bridges. Volume 2: Highway structures: Design (substructures and special structures), Materials. Section 1: Substructures. Part 4. BA 68/97, Crib Retaining walls, February 1997.

[5] Jarominiak A.: Lekkie konstrukcje oporowe, Warszawa, Wydawnictwa Komunikacji i Łączności, 2000. 
[6] Phi Group Ltd: Permacrib Retaining walls, materiały informacyjne, http://www.phigroup.co.uk/solutions/permacrib-timber-crib-retaining-walls, z dnia 06.2010.

[7] Terlikowski W.: Rola badań w procesie rewitalizacji budynków zabytkowych, Miesięcznik Materiały Budowlane 8’2013 (nr 493), Warszawa 2013.

[8] Terlikowski W.: Aspekty techniczne i inżynierskie konserwacji starożytnych konstrukcji murowych jako trwałej ruiny, Miesięcznik Materiały Budowlane 11'2013 (nr 496), Warszawa 2013.

[9] Terlikowski W., Krzemiński R.: Wykorzystanie kaszyc do wzmocnienia wzgórza zamkowego, Miesięcznik Materiały Budowlane 03’2014 (nr 499), Warszawa 2014.

[10] Thakaa Alkhafaji, Henryk Zobel, Mosty drewniane - konstrukcje przełomu XX i XXI wieku, Warszawa, Wydawnictwa Komunikacji i Łączności, 2006.

\title{
TIMBER CRIB RETAING WALLS HISTORIC ELEMENT OF REGENERATION FOR MONUMENTS
}

\begin{abstract}
S u m m a r y
Timber crib retaining walls as massive retaining walls are used from about the VII century to the strengthening of embankments and slopes, riverbanks, streams and landslides, ensuring the stability of the steep shores and protecting their base against blur. 3D structure filled with permeable material fits perfectly in the design requirements where the problem becomes hydrostatic, settlement, noise and aesthetics. Crib walls structure has high formability and affects significantly the resistance to differential settlement. Even settlement about few centimeters differences doesn't damage the retaining structure. The advantage of such feature is the possibility of foundation crib walls at the level in freezing zone. It is also possible to fill the retaining structure with climbing vegetation which improves the positive effect of aesthetic and underlines the complex historical values. Conservation guidelines put one of the major issues typing a strengthening structure in the historic appearance of the surroundings of the monument and above all, do not worsen his aesthetic. An example of such a building is the ruins of a castle on the hilltop castle in Sochaczew. In 2013, has been made the stabilization of the castle hill using soil nails, a massive retaining wall and reinforced embankments with geosynthetics. The final result of strengthening the castle hill with timber crib retaining wall is the creation of a wooden box filled with mineral aggregate with length $79.8 \mathrm{~m}, 1.65 \mathrm{~m}$ width and $4: 1$ slope of the retaining wall. The article presents strenghtening embankment with a timber crib retaining wall.
\end{abstract}

Keywords: massive retaining wall, retaining wall, crib wall, crib retaining wall, monument, embankments strengthening, landslides strengthening

Przestano do redakcji: 23.03.2015 $r$.

Przyjęto do druku: 22.06.2015 r.

DOI:10.7862/rb.2015.51 